\title{
EFFECTS OF IN-VITRO TREATMENT OF BOAR SPERMATOZOA WITH TEPA ON THE FERTILIZATION AND DEVELOPMENT OF PIG EGGS
}

\author{
V. G. PURSEL, L. A. JOHNSON AND A. B. BORKOVEG* \\ Animal Physiology and Genetics Institute, and \\ *Agricultural Environmental Quality Institute, U.S. Department of Agriculture, \\ Beltsville, Maryland 20705, U.S.A.
}

(Received 20th May 1975)

Numerous studies have demonstrated the value of using heterospermic inseminations for comparing the fertilizing capacity of males (Edwards, 1955; Beatty, 1957, 1960; Beatty et al., 1969; Stewart et al., 1974; Overstreet \& Adams, 1971; Martin \& Reimers, 1973) and for assessing sperm treatments (Roche et al., 1968; Miller et al., 1969; Dziuk, 1970; O'Reilly et al., 1972). Overstreet \& Adams (1971) and Bedford \& Overstreet (1972) showed that X-irradiation of rabbit spermatozoa in vitro effectively 'marked' the sperm nucleus without affecting the fertilizing capacity. Ova fertilized by the 'marked' spermatozoa have retarded cleavage. The 'marked' spermatozoa were mixed with unmarked spermatozoa from the same ejaculate and used to test the comparative fertilizing capacity after different sperm treatments were superimposed on the two sperm populations.

Taber \& Borkovec (1969) found that in-vitro treatment of honey bee spermatozoa with the chemosterilant TEPA (Tris(1-aziridinyl)phosphine oxide) caused death of all eggs fertilized by the treated spermatozoa. The research reported in this paper was conducted to determine whether TEPA could effectively 'mark' boar spermatozoa in vitro for use in competitive fertilization experiments involving frozen spermatozoa.

Preliminary results showed that the addition of $0 \cdot 1-10 \mathrm{mg}$ TEPA $/ \mathrm{ml}$ boar semen had no adverse effect on sperm motility or acrosome morphology. Subsequently, 9 gilts were inseminated with boar spermatozoa that had been treated with $0.1,1.0$ or $5.0 \mathrm{mg}$ TEPA $/ \mathrm{ml}$ semen (Table 1). Fertilized eggs were recovered from 8 gilts 144-168 hr after oestrus, but the cleavage rate of the fertilized eggs was severely retarded. Whereas morulae or blastocysts were expected (Hancock, 1961), single-cell eggs with pronuclei and two- to eight-cell eggs were found (Table 1). The number of blastomeres decreased as the levels of TEPA increased $\left(\chi^{2}=25.36 ; P<0.005\right)$.

To test whether TEPA-treated boar spermatozoa could compete equally with untreated boar spermatozoa, gilts were inseminated intracervically with (1) $6 \times 10^{9}$ untreated frozen spermatozoa (U); (2) $6 \times 10^{9}$ TEPA-treated fresh spermatozoa (T); or (3) $3 \times 10^{9}$ untreated frozen spermatozoa and $3 \times 10^{9}$ TEPA-treated frozen spermatozoa $(U+T)$ from the same boar or from the same pool of semen from two or more boars. Each gilt received two inseminations of 
Table 1. Cleavage stage of eggs recovered from gilts inseminated with TEPA-treated boar semen

\begin{tabular}{ccccccc}
\hline $\begin{array}{c}\text { TEPA/ml } \\
\text { semen } \\
(\mathrm{mg})\end{array}$ & Total & 1-cell & 2-cell & 3-cell & 4-cell & 5- to 8-cell \\
\cline { 2 - 7 } & & 1 & 14 & 5 & 2 & 12 \\
\hline $0 \cdot 1$ & 34 & 1 & 17 & 3 & 4 & 2 \\
$1 \cdot 0$ & 34 & 8 & 9 & 5 & 2 & 0 \\
$5 \cdot 0$ & 24 & 8 & & & & \\
\hline
\end{tabular}

the same treatment. Inseminations were made 25 and $42 \mathrm{hr}$ after detection of oestrus.

The sperm-rich fraction of semen from mature boars was used (sperm concentration $\left.5-10 \times 10^{8} / \mathrm{ml}\right)$. TEPA $(10 \mathrm{mg} / \mathrm{ml})$ was dissolved in Beltsville $\mathrm{Ll}$ extender (Pursel et al., 1973), and $1 \mathrm{mg}$ TEPA was added per $\mathrm{ml}$ semen about 90 min after collection. Ten minutes after TEPA was added, each sample was centrifuged at $300 \mathrm{~g}$ for $10 \mathrm{~min}$ and the seminal plasma was removed. Spermatozoa were resuspended to $5 \mathrm{ml}$ with Beltsville F5 extender (Pursel \& Johnson, 1975 ) and centrifugation repeated to remove the excess TEPA. Untreated samples were processed in the same manner. Samples that were frozen were subsequently processed by the procedure of Pursel \& Johnson (1975). For the $\mathrm{U}+\mathrm{T}$ inseminations, the thawed spermatozoa were mixed just before insemination.

Eggs were recovered from the gilts $162 \mathrm{hr}$ after the onset of oestrus, fixed in $25 \%$ acetic alcohol for at least $24 \mathrm{hr}$, stained with aceto-orcein and examined as whole mounts for cleavage and nuclear development.

Eggs that were fertilized with untreated frozen spermatozoa (U, Table 2) were primarily blastocysts (32) or morulae (11). Six eggs had fewer than 16 nuclei and were probably cleaving abnormally due to fertilization of aged eggs (Hunter, 1967). Most of the eggs fertilized by TEPA-treated fresh spermatozoa (T) had 2-4 nuclei/egg, but a few eggs had 5-15 nuclei.

The mixed inseminations of TEPA-treated and untreated frozen spermatozoa $(\mathrm{U}+\mathrm{T})$ resulted in fertilization of 105 eggs (Table 2); 54 eggs contained 2-4 nuclei, indicating that they had been fertilized by TEPA-treated spermatozoa, and 46 eggs were developing normally ( 36 blastocysts and 10 morulae),

Table 2. Egg development in gilts inseminated with untreated frozen $(\mathrm{U})$, TEPA-treated fresh $(\mathrm{T})$ or mixed $\mathrm{U}+\mathrm{T}$ frozen spermatozoa

\begin{tabular}{|c|c|c|c|c|c|c|}
\hline \multirow[b]{2}{*}{ Semen } & \multirow{2}{*}{$\begin{array}{c}\text { No. of } \\
\text { gilts }\end{array}$} & \multicolumn{4}{|c|}{ No. of fertilized eggs recovered } & \multirow{2}{*}{$\begin{array}{c}\text { No. of } \\
\text { unfertilized } \\
\text { eggs }\end{array}$} \\
\hline & & Total & $\underset{\text { nuclei }}{\leqslant 4}$ & $\begin{array}{l}5-15 \\
\text { nuclei }\end{array}$ & $\begin{array}{l}\geqslant 16 \\
\text { nuclei }\end{array}$ & \\
\hline $\begin{array}{l}\mathrm{U} \\
\mathrm{T} \\
\mathrm{U}+\mathrm{T}\end{array}$ & $\begin{array}{r}5 \\
5 \\
10\end{array}$ & $\begin{array}{r}57 \\
59 \\
117\end{array}$ & $\begin{array}{r}0 \\
51 \\
54\end{array}$ & $\begin{array}{l}6 \\
6 \\
5\end{array}$ & $\begin{array}{r}43 \\
0 \\
46\end{array}$ & $\begin{array}{r}8 \\
2 \\
12\end{array}$ \\
\hline
\end{tabular}


indicating that they had been fertilized by untreated spermatozoa. The identity of the fertilizing spermatozoa for the eggs with 5-15 nuclei could not be determined.

For the $\mathrm{U}+\mathrm{T}$ inseminations (Table 2), there was no significant difference between the number of eggs with 4 or less nuclei $(5.4 \pm 0.91$ (S.E.)/gilt) and the number of eggs with 16 or more nuclei $(4 \cdot 6 \pm 0 \cdot 60$ (S.E.)/gilt; $P>0 \cdot 10)$.

Eggs that were fertilized by TEPA-treated spermatozoa and recovered at $162 \mathrm{hr}$ after the onset of oestrus required nuclear staining to be distinguished from unfertilized eggs because both populations of eggs frequently underwent fragmentation and cytoplasmic degeneration.

Single-cell eggs usually contained 2, but occasionally 3, pronuclei. Eggs with 2-4 blastomeres usually contained one nucleus/blastomere but one or more nuclear buds or sub-nuclei were observed in some blastomeres. The nuclear and cytoplasmic degenerative changes observed in this study were similar to those reported by Amoroso \& Parkes (1947) and Chang et al. (1957) for rabbit eggs fertilized with irradiated spermatozoa.

The use of TEPA as a sperm marker has three major advantages over the use of a genetic marker for conducting competitive fertilization tests. First, treatments can be compared within an ejaculate rather than between ejaculates from two males of differing genetic composition. Second, the results can be assessed within a week rather than waiting an entire gestation period. Finally, when a genetic marker is used the results are based on fetuses or offspring, and embryonic and fetal deaths may reduce the number of observations/female.

In conclusion, TEPA-treated boar spermatozoa can compete equally with untreated spermatozoa for fertilizing eggs. Most of the eggs fertilized by TEPAtreated spermatozoa can be distinguished because of delayed cleavage. TEPAtreated boar spermatozoa are now being used in competitive fertility testing of various semen storage procedures involved with freezing of boar spermatozoa.

\section{REFERENCES}

Amoroso, E.C. \& PARKes, A.S. (1947) Effects on embryonic development of X-irradiation of rabbit spermatozoa in vitro. Proc. $R$. Soc. B 134, 57-78.

BEATTY, R.A. (1957) A pilot experiment with heterospermic insemination in the rabbit. 7. Genet. 55, 32.5-347.

Beatty, R.A. (1960) Fertility of mixed semen from different rabbits. F. Reprod. Fert. 1, 52-60.

Beatty, R.A., Bennett, J.H., Hale, J.G., Hancock, J.L. \& Stewart, D.L. (1969) An experiment with heterospermic insemination in cattle. J. Reprod. Fert. 19, 491-502.

BEDFORD, J.M. \& OvERSTREeT, J.W. (1972) A method for objective evaluation of the fertilizing ability of spermatozoa irrespective of genetic character. F. Reprod. Fert. 31, 407-414.

Chang, M.C., Hunt, D.M. \& Romanoff, E.B. (1957) Effects of radiocobalt irradiation of rabbit spermatozoa in vitro on fertilization and early development. Anat. Rec. 129, 211-224.

Dziuk, P. (1970) Estimation of optimum time for insemination of gilts and ewes by double mating at certain times relative to ovulation. $\mathcal{F}$. Reprod. Fert. 22, 277-282.

EDwards, R.G. (1955) Selective fertilization following the use of sperm mixtures in the mouse. Nature, Lond. 175, 215-216.

Hancock, J.L. (1961) Fertilization in the pig. F. Reprod. Fert. 2, 307-331.

HunTER, R.H.F. (1967) The effects of delayed insemination on fertilization and early cleavage in the pig. F. Reprod. Fert. 13, 133-147.

Martin, P.A. \& Reimers, T.J. (1973) Relationship between fertility levels of cocks measured by homospermic and heterospermic inseminations. Biol. Reprod. 9, 85-86.

Miller, O.G., Roche, J.R. \& DziuK, P.J. (1969) Estimation of the optimum interval between insemination and ovulation in the rabbit by double insemination. F. Reprod. Fert. 19, 545-546. 
O'Reilly, P.J., Graves, C.N. \& Dziuk, P.J. (1972) Heterospermic insemination of rabbit semen as a means of evaluating techniques of semen handling. J. Reprod. Fert. 29, 49-56.

Overstreet, J.W. \& Adams, C.E. (1971) Mechanisms of selective fertilization in the rabbit: sperm transport and viability. F. Reprod. Fert. 26, 219-231.

Pursel, V.G. \& Johnson, L.A. (1975) Freezing of boar spermatozoa: fertilizing capacity with concentrated semen and a new thawing procedure. F. Anim. Sci. 40, 99-102.

Pursel, V.G., Johnson, L.A. \& Schulman, L.L. (1973) Fertilizing capacity of boar semen stored at $15^{\circ} \mathrm{C}$. 7. Anim. Sci. 37, 532-535.

Roche, J.F., Dziuk, P.J. \& Lodge, J.R. (1968) Competition between fresh and aged spermatozoa in fertilizing rabbit eggs. F. Reprod. Fert. 16, 155-157.

Stewart, D.L., Spooner, R.L., Bennetr, G.H., Beatty, R.A. \& Hancock, J.L. (1974) A second experiment with heterospermic insemination in cattle. 7 . Reprod. Fert. 36, 107-116.

TABer, S. \& Borkovec, A.B. (1969) Chemical sterilization of honey bee spermatozoa in vitro. Nature, Lond. 224, 1217-1218. 